\title{
Polemical Comparisons in the Apology against the Christian Religion by Muhamad Alguazir (c. 1610)
}

\author{
GERARD WIEGERS \\ University of Amsterdam, School for Historical Studies, Amsterdam, The Netherlands \\ MERCEDES GARCÍA-ARENAL \\ CSIC Madrid, Spain
}

\begin{abstract}
This essay analyses the comparisons made in the Apology against the articles of the Christian Religion by Muhamad Alguazir (c. 1610). Alguazir, a Morisco from Pastrana (Spain), was one of the Moriscos living at the court of sultan Mawlay Zaydan (1608-1627). The polemical treatise he wrote was sent to Maurice of Orange shortly after the conclusion of a treaty of friendship between Zaydan and the Dutch (in 1610) and translated into Latin. The polemic had a two-pronged later influence: on European debates about the Trinity; and it was used by Anti-Trinitarians and by German Lutherans in their polemics against them, on the one hand, and by Moriscos living in Tunis, viz. the expelled Toledan Morisco Juan Pérez aka Ibrahim Taybili, on the other. We study the transformations that the polemic underwent according to the translations and the religious transfers.
\end{abstract}

KEYWORDS religious polemics, Spain, Moriscos, Morocco, Dutch Republic, Tunis, antitritarianism

\section{Introduction}

Around the year 1610, a Morisco-a descendant of Spanish Muslims who were converted under duress to Roman Catholicism-was living in exile at the court of the sultan of Marrakesh, Mawlāy Zaydān al-Sa ${ }^{c}$ di (r. 1608-1627). ${ }^{1}$ This Morisco wrote a polemical treatise against Christianity titled Apología contra la ley Cristiana, which has survived in only two manuscripts, both written in seventeenth-century Spanish hands. Both manuscripts-one held at the Biblioteca Nacional de España (National Library, Spain) and the other at Wadham College, Oxford-consist mainly of a 'contradiction' (contradicción) or rebuttal of Christianity, which makes this study an excellent source for a study on notions of comparing religion in

1 On the expulsion and diaspora of the Moriscos, see e.g. García-Arenal and Wiegers (2014b). 
polemics such as we undertake here. ${ }^{2}$ The Apología is not only written in Spanish but is, moreover, aimed at a Christian audience, as Wiegers has argued elsewhere. ${ }^{3}$ Its author explains that he undertook the task of writing it at the request of Mawlāy Zaydān, who took power in Marrakesh around 1608.

What is known of the author is little more than what he himself reports in his text: his name, Muhamad Alguazir, and that he was part of the entourage of Mawlāy Zaydān in Marrakesh after migrating from his native Pastrana in Castile. Pastrana was an important centre of Morisco intellectual activity and a city to which many Granadan Morisco migrated after the revolt of the Moriscos in Granada in $1571 .{ }^{4}$ As we know from other sources, Mawlāy Zaydān employed various Moriscos at his court. Alongside Muhamad Alguazir, whose official functions are unknown, we also hear about a Morisco from Córdoba, ${ }^{\mathrm{c}}$ Alī b. Ibrāhīm al-Qurțubī, who was a court physician, and Ahmad al-Mașyūb, the court astrologer. Some of these Moriscos at the $\mathrm{Sa}^{\mathrm{c}}$ did courts were engaged in translating Arabic texts into Spanish, sometimes in their capacity as official interpreters. This was the case, for instance, with Aḥmad b. Qāsim al-Hajarī, who also wrote (in his case in Arabic) a well-known work of polemics against Christianity and Judaism. ${ }^{5}$ It also appears possible, therefore, that al-Hajari is referring to "our" Muhamad Alguazir in a letter, written in Paris in 1612 to Moriscos in Istanbul, about the emigration of several expelled Morisco scholars. He tells his friends in Istanbul that one "Mr Alguaçil has gone to Marrakesh" (Wiegers 1988, 43). In any case, since al-Hajarī lived in Marrakesh from about 1599 onwards, it is more than likely that he and Alguazir knew each other.

Based on Inquisition materials, we know there was a Morisco family in Pastrana with the surname Alguacil. Diego Alguacil was denounced to the Inquisition for his knowledge of "Moorish prayers" and of Islam. Indeed, his knowledge was so extensive that he was held in esteem by other Moriscos as an archivo vivo ("living archive") (García-Arenal and Rodríguez Mediano 2010, 612). This same expression also shows up in the Apología, and is not the only term or phrase there that overlaps with the Inquisition testimonies on Diego Alguaçil, such as the use of the term máquina for the 'mechanism,' i.e., the movements, of the world (mundo). Thus, this overlap is further evidence that the Diego investigated by the Holy Officewho successfully fled before 1613 - may have been the same man as our author, Muhamad Alguazir (García-Arenal and Rodríguez Mediano 2013, 142:293). Furthermore, the Morisco descent of the author of the Apología is corroborated by Ibrahim Taybili, an expelled Morisco who settled in a Tunisian village, Testour, founded by Moriscos. In his own work, Taybili mentions that Muhamad Alguazir was a former inhabitant of Pastrana (Castile), "who is now [Taybili was writing in 1037/1627-28] an inhabitant of Marrakesh." ${ }^{6}$ Taybili provides his own Spanish Christian name (Juan Pérez) but does not cite the Christian name of Alguazir.

2 BNE Ms. 9074 and Wadham College, Oxford, Ms. A18-15; see on the Madrid manuscript the literature mentioned below, on the Wadham manuscript, see Harvey (1989).

3 On Alguazir, see Wiegers (2010, 1996, 2017a). We have in the present text made use of earlier studies on Alguazir by Gerard Wiegers.

4 On Pastrana, see Alegre Carvajal (2020) and the sources referred to by her.

5 On al-Hajarī, see, for example, the recent article by Wiegers (1988); Van Koningsveld, Al-Samarrai and Wiegers (2015); Wiegers (2010). It should be noted that al-Hajarī's views on Christianity cannot be detached from his views on the Granadan Sacromonte Lead Books and the Turpiana Tower parchment, which he was asked to interpret, but also on the Hebrew Bible and the Protestant Spanish Bible Translations; see also his discussions with Jews in Amsterdam in chapter ten of his Supporter.

6 "y abiendo bisto un libro que a mis manos bino cuyo autor fue Muhamad Alguaçir, beçino que fue de Pastrana, y al pressente de la ynsigne çiudad de MaRuecos [sic] en que contradiçe la falssa ley cristiana"; see on him Bernabé Pons (1988), Galmés de Fuentes and Villaverde Amieva (2005), Bernabé Pons (2017). All quotations from Spanish into English are by the authors unless indicated otherwise. 
Alguazir's work is probably one of the earliest texts written by a Morisco in exile after 1609. It can be dated between 1609-the year in which the expulsion of the Moriscos began, an event to which Alguazir explicitly refers in the text-and 1612, the year in which the text was sent to Maurice of Nassau and dated.

As we said at the beginning, the aim of this essay is to analyse the way Alguazir employs polemical comparisons in his Apología contra la ley Cristiana, and to examine how these comparisons are rendered in the Latin translation and in the poem by Taybili. ${ }^{7}$ We will be considering whether these comparisons vary in the two different adaptations of Alguazir's text, analysing whether and how they were adapted to the respective audiences targeted in each version, and how these changes in the comparisons transform the different texts. ${ }^{8}$ As we will see, the main groups that appear in these polemical comparison are Christians versus Muslims and Muslims versus Jews, but as we will observe below, the polemical comparisons then turn to differences between Christian denominations as well. Protestants are opposed to Catholics, and within Protestantism Trinitarians are compared to anti-Trinitarians. Finally, we will evaluate the functions of these polemical comparisons in the wider framework of comparing religions in the Early Modern Period and interreligious polemics.

\section{The Influence of Alguazir's Apología in Europe and the North African Morisco Diaspora}

A large part of the texts known to have been written by Moriscos in the Diaspora are polemical in nature. Several of these texts were aimed at the re-Islamization of the Moriscos, and were clearly meant for a Morisco readership. Others, however, were originally addressed to a Christian audience. Alguazir's treatise is an excellent example of the second category. It became one of the most important sources for nearly all future anti-Christian works written by Moriscos in Spanish between 1612 and 1639; in this period, Spanish is known to have been used as a written language among Muslims from Iberia exiled throughout North Africa and the Ottoman Empire (García-Arenal and Wiegers 2014a).

The polemical treatise written by Alguazir has witnessed a remarkable 'double action' that we will analyse in this essay. In a first instance, the Spanish treatise was sent in 1612 to the city of The Hague in the Dutch Republic in the name of a Moroccan ambassador to the Republic, Aḥmad b. ${ }^{c}$ Abd Allāh al-Ḥaytī al-Marunī, where the seven chapters that probably formed the most original part were translated into Latin by a person whom we have so far not been able to identify (Wiegers 2017a). A copy of this translation was brought to England, perhaps by the well-known jurist and orientalist John Selden (1584-1654), who held it for some time (Ben-Abdala 1705, 3); indeed, today it can be found among the Bodleian Library's Selden manuscripts (Ms. Arch. Selden B 8), at Oxford (Craster, Denholm-Young, and Madan 1980, 2:594-95). This manuscript provides some very interesting new information about the history of the polemical treatise, as will be seen below. The manuscript was read and used by anti-Trinitarians and Unitarians, and printed in 1709 by a man called Zacharias Grapius.

However, in a second instance, Alguazir's treatise was also versified by Ibrahim Taybili,

7 On Morisco polemics, see, e.g., Cardaillac (1977); on polemics between Jews, Christians and Muslims, García-Arenal and Wiegers (2019); on Mudejar polemics, Colominas Aparicio (2018). For a comparative historical approach to medieval and early-modern polemics, Steckel (2018) and Colominas (2020). A comparative study of the literary aspect of both texts is found in Balabarca (2020). 
the aforementioned Morisco exiled in the Tunisian village of Testour. Taybili's Spanish poem, Contradictión de los catorce artículos de la ley Cristiana, was widely read among Moriscos in the North African diaspora. Taybili, as he himself explains, wrote his Contradictión in verse so that it would be easier to memorize, with the aim of teaching the Spanish-speaking Morisco exiles about the boundaries between Christianity and Islam, and contributing to their reIslamization. Therefore, Alguazir's text was the object of different uses and adaptations.

\section{Alguazir's Apología contra la ley cristiana: Its Contents}

We will begin our analysis of the polemical comparisons in the works of Aguazir and Taybili by describing the contents of the Apología contra la ley cristiana. Its main intention is, according to its author, who introduces himself as Muhamad Alguazir (Wadham: Alguaçir), to steer Christians away from their heretical belief in the Trinity and lead them toward belief in divine Unity. In order to examine how comparisons between various religions are used in Alguazir's text, we will discuss all places where it compares Muslims with other religious groups, namely Christians, Jews and pagans. The main comparison, as the title indicates, is with Christians. Alguazir always refers to them as "Christians," though given his Spanish origin he clearly is talking specifically about Roman Catholics.

The introduction is basically devoted to explaining that Christian beliefs are based on the Apostolic Creed, which contains 14 articles. The Apostolic Creed is quoted here in a particular form that goes back to Thomas Aquinas, and which was known to have been used in many antiIslamic texts used by missionaries who preached to the Moriscos. ${ }^{9}$ This shows that Alguazir was current with the Christian theology of his time. It is divided into seven articles pertaining to Christ's humanity and seven articles pertaining to His divinity. ${ }^{10}$

\section{Chapters 1-4}

The first four chapters explicitly deal with a refutation of the articles of the Apostolic Creed described above.

Chapter One (f. 6v-f. 26r) is devoted to the first four articles. According to the author, these four articles (which he calls atributos) contradict each other to such an extent that there is almost no need for a logic-based refutation (contradizión). He argues that reason is incapable of understanding how God could simultaneously be Father and Son, in addition to the Holy Ghost. And yet, he says, Christians circumvent logic by maintaining that it is a mystery, whereas Muslims know that God endowed man with reason in order to accept what is possible and necessary, and to reject what is impossible. ${ }^{11}$ In order to explain the Trinity, the Christians compare it to the sun, which at the same time is the sun [i.e. matter], heat

9 Secunda Secundae Summa Theologiae, Aquinas (1895), Quaestio 1, articulus VIII.

10 "Los articulos de la fee son catorze. Los siete perteneçen a la dibinidad y los otros siete a la humanidad. Los siete primeros creher en un solo Dios todopoderoso. El segundo creher qu'es padre, el terzero creher qu'es hijo, el quarto que es espritu sancto, el quinto creher qu'es criador el ssesto que es salvador, el ssetimo creher qu'es Glorificador. Y los siete que perteneçen a la humanidad son estos, el primero qreer que Chisto en quanto hombre fue conçebido por hobra de spritu santo, el sigundo que nazió de santa Maria birgen antes del parto y en el parto y después del parto, el terçero que rrezibió muerte y passión por ssalbar los pecadores, el quarto que bajó a los infiernos y sacó a las ánimas de los sanctos padres que estaban aguardando su sancto aduenimiento, el quinto que resuzitó al terzero día, el sesto que subió a los zielos y esta assentado a la diestra de Dios padre, el sétimo que bendrá a Juzgar a los bibos y a los muertos, para dar gloria a los buenos y pena a los malos" (BNE Ms. 9074, f. 5r-6r). f. 7 r. 
and light, while Muslims (throughout the text he uses the term moros) reply that the heat of the sun is an activity of the sun, not the sun itself. Thus, the Christians in fact maintain, in spite of their intentions, that the son is God's creation, and not of the same essence. At other times, they compare the Trinity to a cloth (paño) folded into three, yet remaining one if unfolded again; to an apple; ${ }^{12}$ or to the spirit, which consists of memory, reason, and will. ${ }^{13}$ Alguazir is obviously well-versed in the sermons of the Spain of his time, such as those of Fr. Hernando de Santiago, nicknamed "Pico de Oro," to whose activity Taybili refers in his own work (Soto 2019). Hernando de Santiago gave sermons in Toledo and the surrounding area in the years in which Alguazir was living in Spain, but he is just one example of preachers Alguazir might have heard (Pérez 1949). More importantly, these Christian metaphors appear in the book of another famous contemporary preacher, Alonso de Vascones, whose sermons were collected in Destierro de ignorancias y aviso de penitentes (printed in Valencia, 1620). It seems as if Alguazir is quoting Vascones verbatim in several passages. For example, Vascones writes: "With regard to the issue that there is a Sun: there are three aspects in it, and all three are the same sun, which are: substance, heat and light of the Sun, and all three are different from each other, but they are not three Suns, but only one. The same is the case with regard to the eternal and inexplanable Trinity."14

Meanwhile, Alguazir writes: "And the examples they give to explain the Trinity is that the sun is one, and three things: heat, light and [the substance of] the sun. To which we respond that the heat of the sun is an act of the sun, not the sun itself." 15

All these comparisons that the Christians propose fail: God, who created from nothing, is One in his Essence, free and above "composition" (compostura) ${ }^{16}$ For much the same reason, they falsely maintain that Christ ${ }^{17}$ is both God's word and God at the same time. ${ }^{18}$ But God, the creator and architect, has created from nothing the "machine" (máquina) ${ }^{19}$ of the heavens and earth, and He did so by means of the attribute of his power, which is part of His essence and cannot be distinguished from it, and He enlightens his Creation with His Grace. Then the author goes on to explain why Christ is called "God's spirit" (espíritu de Dios) in Islam (f. 18r-f. 20v), and that one should perceive his miracles as divine miracles, like the raising of the dead and the curing of the ill, which other earlier Prophets like Elijah ${ }^{20}$ had also performed. All the prophets are capable of performing such miracles, especially the Prophet Muhammad, as we know from the miracles described in the book of Qādī c Iyād,. ${ }^{21}$ Returning to his discussion of the Trinity, the author mentions the fact that in earlier times the Christians used to explain the Trinity in terms quite different from those used by his contemporaries, for example by using the concept of the aqānim (sing. uqnūm, hypostasis), ${ }^{22}$ the inconsistency of which reveals the futility of their arguments. The author's Muslim contemporaries and

12 f. $11 \mathrm{r}$.

13 f. $11 \mathrm{v}$

14 "Como al punto que ay Sol ay tres cosas en él y todas son el mismo Sol, que son sustançia del Sol, calor del Sol y luz del Sol, y todas estas tres cosas son distintas realmente entre sí y no son tres soles sino un solo Sol. Ansí en la eternal e ineffable Trinidad..."

"Y los ejemplos que ellos dan para dar a entender esta Trinidad, diçen que es como el sol que es uno y son tres cosas, calor, resplandor i sol. A las quales se responde que el calor del sol es hobra del sol y no el mismo sol...." f. 8v.

16 f. $12 v-f .13 r$.

17 Throughout the text the author writes "Chisto" [sic], not Jesus.

18 f. $13 \mathrm{v}$-f. 17(b)r (folio 17 is numbered twice).

19 On this term, see above.

20 f. $21 \mathrm{r}$.

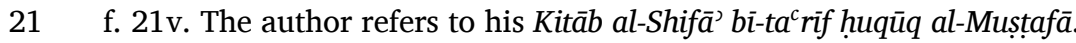

22 f. $23 \mathrm{v}$, and see further below. 
predecessors, such as Muhammad b. Yūsuf al-Sanūsī, however, have persisted in giving the same answers to the Christians. ${ }^{23}$ Taken as a whole, these passages seem to contribute to building an overall polemical contrast between the consistent and constant Muslim beliefs and teachings, and the contradictory and changeable Christian teachings. Along these lines, Alguazir emphasizes that God's essence is indivisible. He rejects and refutes various Christian explanations as to the two natures of $\mathrm{Christ}^{24}$ as an illogical admixture of the Divine world and the world of Creation.

Chapter Two (f. 26r-f. 34r) deals with the three articles which state that Christ is Creator, Saviour and Glorifier. While Christians say that Christ is the Creator, Alguazir counters that this cannot be true for a number of reasons, of which he enumerates ten, the first being that this would imply that there are creators, which obviously cannot be true. With regard to the Christian statement that He is the Glorifier (glorificador) and Saviour (salbador), the same objections can be made, as the author explains. ${ }^{25}$ Some additional reasons could be given, for example, that it is the Creator who saves and grants glory, and not a created being, to which category (according to the Christians themselves) Christ also belongs. This in itself shows once more the logical inconsistency of the Christian position, as the author explains at length.

Chapter Three (f. 34r-36r) deals with the articles stating that Christ was conceived of the Holy Ghost, and that he was born of Saint Mary, who remained a virgin before, during and after giving birth. The errors in these two articles are hidden (encubierto) because the Muslims also say that his soul was the Holy Ghost and that he was God's Spirit [Ar. rūh Allāh], and conceive his birth as a miracle comparable to that of Adam, who likewise had no human procreator. With respect to Christ, the Muslims adopt a middle position (which is where truth is always to be found $)^{26}$ between the Jews and the Christians: they consider Jesus to be a Prophet, but not God's son, nor do they think that His conception and birth "were sinful and that he led an evil and dishonest life, as the cursed Jews do."27

Chapter Four deals with the articles which say that one should believe that Christ suffered and died in order to save mankind, descended into Hell, and saved the Holy Fathers, all this in order to expiate Adam's sin, and that he was raised from the dead on the third day. First of all, the author again gives an overview of the Christian views in order to then refute them. Here Alguazir's main argument to the contrary is that the person crucified was very probably Judas, who, forced to assume Jesus's physique as a result of a miraculous transformation, was arrested and subsequently crucified. ${ }^{28}$ According to the author, this identification is in harmony with several passages in the Gospels. Although the author does not state it explicitly here, this identification is also in accordance with Islamic dogma that it was not Jesus who was

f. $22 \mathrm{v}$.

f. $24 \mathrm{v}$.

f. 30 r.

f. $35 \mathrm{v}$.

"y el otro estremo de los maldictos judíos diziendo de un proffeta menssajero de Dios criado por grazia y milagro de madre virgen onesta y sancta que era enjendrado en pecado y que era de maluivir mentirosso" (f. 35r-v).

28 "y el cruzificado por oculto juizio de Dios fue un hombre en la misma semejança de Chisto [sic] el qual se entiende ser Judas el que como traidor procuro bendelle a los judíos anssí quando entró disimulado adonde Xpto estaba en el guerto con los dizípulos para abelle de entregar con el besso de paz hordenó Dios quel Judas tomando la semejanza de Xpo le assieron a él, y a Chisto [sic] le alçó Dios a los çielos sacándole de entre ellos y, siendo como es, anssí biene bien co [sic] lo quel hixo del ortelano dijo aber bisto un bulto blanco y desaparezerse" (BNE Ms. 9074, f.40r). On Judas as a substitute, see the Gospel of Barnabas, Bernabé Pons (1998, 303); see for another view on the substitution van Koningsveld and Wiegers (2019) (includes an edition and translation of the Lead Book text of the Life of Jesus and his mother Mary, Lead Book no. 7 of the Sacromonte). For a further analysis see Wiegers (1995). 
crucified, but rather a similar-looking stand-in (see Q.4:156-7). Jesus himself was raised into Heaven by almighty God, whence he will return at the End of Time to punish heretical beliefs and rule in peace, before being buried inside the Dome that houses the Prophet's tomb, on the Prophet's right-hand side, after which the Day of Judgement will be imminent. ${ }^{29}$ Both the idea that Jesus was not crucified, but another person in his place, and the notion that he will be buried beside Muhammad in the dome housing his grave in Medina, are frequently found in Islamic texts, including those written by Mudejars and Moriscos (Cardaillac 1977, 287). The most important reference and probably the earliest is provided by the faqih of Segovia, Iça de Gebir, in his Breviario Sunni. ${ }^{30}$ Again, in this chapter the author draws attention to many contradictory aspects of Christian beliefs, all of which is taken to prove the superiority of Islam. This superiority can also be perceived in daily life: while the oppressed and recently expelled Muslims of Spain ${ }^{31}$ never stopped practicing Islam, the children of Christian converts to Islam always become good Muslims. ${ }^{32}$ He then goes on to explain basic Muslim beliefs, such as the belief in God's Unity, on the basis of a number of Qur'ānic verses, quoted here in Spanish, ${ }^{33}$ and adds a few words explaining the ceremonies ( ${ }^{c} i b \bar{a} d \bar{a} t$ ) (f. 48r-f. 48v). The argument then returns to the Gospels and to the concept of tahrif, i.e., the accusation that the scriptures have been altered (though not explicitly expressed, f. 49r-f. 49v). In this view, the extant Gospels include neither divine nor human laws (leyes divinas ni humanas, f. 49v), such that the Christians are unable to base their laws on the scriptures, relying on gentile Roman Law instead. The result is a situation which amounts to "lawlessness" (f. 50v). ${ }^{34}$ This shows their depravation, which becomes especially evident when they punish people for not believing that God has a son, etc. (f. 51r-f. 51v). Moreover, the author argues that the Messiah promised in the Law is in fact the Holy Prophet Muhammad. ${ }^{35}$ In the same vein, he goes on to discuss celibacy (for Roman Catholic priests) as a human invention in outright contradiction to Divine Law and human nature, resulting in the birth of many illegitimate children (f. 52r-f. 53v). At the end of his discussion of the Apostolic Creed, the author concludes that what the Christians call the "law of grace" (ley de gracia) amounts to an erroneous, contradictory (oppusitibal) and

29 "A los quales respondemos que Chisto no murió sino que Dios ognipotente le alçó a los zielos adonde esta agora. A de bolver al mundo a castigar las eréticas opiniones que contra sus euangelios [Wadham College Ms. f. 44v, "su euangelio"] lebantaron. Reynará los años que Dios quisiere tan fértiles y tan pasíficos que pareçerán a la jente quatro días y morirá. Se enterrará dentro del alcaba [sic, for alcuba] de nuestro sagrado profeta Muhammad a su lado derecho y de allí a breve tiempo finara el mundo anssí como Elias, librándolo de los judíos que lo procuraban matar [...] " f. 39v. The error was noticed by Taybili, see Bernabé Pons (1988, 191).

30 In Wiegers (1994), appendix 4.

31 A clear indication that the work was written after 1609.

32 "como bemos que en mas de zien años después de la conquista de España por los chistianos jamás salieron de ssu ley los decendientes de moros hasta que agora en nuestros tiempos los desterraron los chistianos della, perdiendo de todo punto las esperanças de que jamás adorarían con ellos las imájenes de corazón haunque cada día los quemaban por moros y al contrario bemos los chistianos en todas las conquistas que abido en el mundo, anssí en España como en las demás tierras en bolbiéndose uno moro lo es de coraçón pues bemos quel que ayer era Xpiano yba contra Xpiano con harmada y mata a los que adoran las imájenes haunque sean sus hermanos y si algunos les queda alguna chistiandad encubierta salen sus hijos buenos moros, lo qual jamás se bee en los hijos de los que an ssido moros y los an echo xpianos por que sus padres con qualquiera raçón que de la ley de dios les dan hobra en ellos y baden uno en uno para siempre" (BNE Ms. 9074, f. 45r-v), see Ben-Abdala (1705, 107).

33 f. $46 r-f .48 r$.

34 "Pues cómo pueden ssaver que Dios está contento de tal justizia, no siendo por escriptura suia ques al contrario del Alcorán sagrado pues no ay sentenzia chica ni grande que de él no se saque, y con él no se justiffiquen las causas como es costumbre en la ley ssacra de Dios y la de los chistianos pussitival, hordenada por los hombres y ffalssa." f. 52r, see Wiegers (1995, 245-46). 
constructed faith, as opposed to a revealed (conpuesta) one. In the next three much shorter chapters, the perspective changes to the Catholic form of three fundamental Christian rituals: the Eucharist, mass, and confession. Nowhere in these three chapters, however, is it made explicit that these rituals are predominantly Catholic; reference is again made to "the Christians" generally.

\section{Chapters 5-7}

Chapter Five deals with the Eucharist (ostia) (f. 54r-57v). The author first describes the ritual, paying particular attention to the transubstantiation and to the words spoken by the priest. The author denies that the host could be God, apparently drawing on his own experience for some of his arguments. He claims to have seen, for example, churches that were struck by lightning or destroyed by other natural disasters, along with the host wafers. How could such things happen if God actually inhabited the host? ${ }^{36}$ If He did, would their destruction not result in His death?

Chapter Six (57v-63r) is about the mass (la missa o ssacriffizio). Again, the author provides an overview of the ritual, which he describes as a gathering of men and women in a temple, during which their priest stands at the altar-above which are pictures of Christ and the Saints, just like the idols worshipped by the gentiles ${ }^{37}$-and raises both a chalice and the host, then goes on to perform the ritual itself. Only a priest is allowed to say mass (dezir missa), which means that if no priest is present, Christians are unable to celebrate mass, which again shows how far they have gone astray. Although places of worship are meant for prayer and for weeping over sin, their mass is accompanied by organs, "the most beautiful musical instruments in the world," 38 and everything is allowed: they speak with each other and do all the same things they would in the marketplace. The author then contrasts this picture with the solemnity of Muslim worship: the adhān, and the words used there (f. 60v); the purity ritual; the performance of the ablutions; the beginning of the salat, when the men cannot see the women; the silence during the service, which is led by someone "they [the Muslims] call the imam" (f. 61v); the salat ritual itself, quoting the Fätiha in Spanish and discussing its significance (f. 61r-f. 63r).

Chapter Seven (f. 63v-67v) describes and refutes the sacrament of confession. Here, he describes the penitent on his knees and telling the priest all his sins, after which he is absolved, no matter how grave his trespasses. Thus, the very grave sin of adultery elicits a mere discretionary penance of carrying a cross on one's back (f. 65v). The author makes it clear that a priest does not have such powers, but rather that only God can meet out punishment or grant rewards. Not the confession of sins to a priest, but only true repentance, may raise the believer's hope for God's forgiveness.

Chapter Eight (f. 68r-123v) is the longest to be found in the treatise, and is fundamentally different from its other parts. Here the author leaves behind his refutation of Christianity, offering instead an exposition of the attributes of God. This is no doubt why it was not included in the Latin translation, as we will show below. While most of it follows the work of al-Sanūsī, surprisingly it also contains long passages taken from Fray Luis de Granada's Introducción del

36 f. $56 v-f .57 r$.

37 "La missa o ssacriffizio de los chistianos es que juntándosse en un templo hombres y mujeres en uno, el ssacçerdote dellos se sube en un altar en el qual tienen ffiguras de ssantos y de Chisto cruzificado, anssí como los idólatras hazían con sus hídolos, y traiendo un basso a quien llaman cáliz, y una ovlea echa de arina a quien llaman ostia."

"una de las mejores mússicas del mundo," f. 59v-f. 60r. 
símbolo de la fe. Fray Luis (1504-1588) was a well-known Dominican friar born in Granada whose work was extremely popular and widespread in Spain, with several printed editions. Alguazir uses the pages in which Fray Luis describes the order of nature as proof of the existence of God (101). Although he never mentions Fray Luis by name, some passages in Chapter Eight paraphrase point by point the metaphors employed in the Símbolo.

Alguazir's use of both Vascones and Fray Luis de Granada leads us to wonder whether Alguazir had already written a polemical work before fleeing the Peninsula (García-Arenal and Rodríguez Mediano 2016, 277-278).

As can be seen from this summary, Alguazir's text is mainly a comparison between two faiths in which the superiority of Islam is constantly demonstrated and underscored. For him, the primordial difference between the two religions is that Christianity is not a Law of God, as Islam is, which has led Christians to rely on other legal systems, such as Roman law. This constitutes a profound difference in conception that Alguazir finds detrimental to Christianity. He also takes issue with the fact that none of the Gospels sets forth religious precepts, or information about Heaven and Hell. There are no laws, divine or human, and hence Christians do not judge their civil and criminal cases on the basis of the Gospels, but on the basis of gentile Roman law, which they adapt in order to suit their governmental needs. In his view, this reliance on a legal system crafted by the pagan Romans is quite severe; if the gentiles were unable to recognize God, whose existence is as plain as day, how can their law be expected to rightly account for sin, guilt, and proper punishment? ${ }^{39}$

Not having a basis in an authentic Divine Law (such as the shari ${ }^{-c} a$ ) has moral implications for Christianity. In fact, if their Gospels, which they claim come from Jesus, do not contain clear precepts for His followers to live by, how can Jesus be taken as a master and a guide for men? Unlike Jesus's original message, the Gospels the Christians read today are mere tales of Christ's life, as human and fallible as the men who put them in writing. ${ }^{40}$ Here, the author implicitly compares the reliability and completeness of the Qur'ān as received by the Prophet Muhammad and the Muslim community to the alleged untrustworthiness and incompleteness of the texts of the four canonical Gospels.

Throughout Alguazir's text, every Christian dogma, every ritual, when held up to the mirror of Islam, is reflected back at a disadvantage. A dual process of analogy and rejection seeks out an Islamic counterpart to each Christian belief or practice. Moreover, there is a general tone of repudiation through comparison. Comparison is all-pervasive, but there is comparatively little invective: most of the refutations are based on logic and reason, aimed at the internal contradictions of the Christian tradition. It is also based on the notion that throughout history Christian beliefs have been subject to alteration, whereas Islamic dogma and ritual has always remained the same, without variations. Thus, the arguments used by the author against the Christians are by no means articulated in terms of violence or fundamentalism, the reasons for which we will return to below.

39 "Y en todos los ebanjelios no ai preçeptos ni abissos de gloria o infierno, ni leyes diuinas ni humanas, y anssí los chistianos no juzgan sus dessabenenzias çibiles y criminales y erenzias por los ebanjelios, sino por las leyes de los jentiles romanos, y las que ellos hordenan en probecho de sus repúblicas. El qual herror es conozido pues en el entendimiento de un jentil que no conozía a dios siendo Dios más manifiesto qu'el sol, cómo podía alcançar la grabedad del pecado y culpa del deliquente o el justo castigo que le debía dar para justificar su delito" (f. 50r-v).

40 "Siendo ansí digan los christianos si Christo es dios y bino a ser maestro a los hombres que libró y escriptura de preceptos dejó escripto pues no les será a los xtianos respuesta decir que de la palabra les enseñó, pues los que le alcançaron no le podían todos seguir sin escriptura, quanto y más los que no le alcanzaron. Y los ebajelios que tienen no son más de como ystoria de su vida de Christo" (f. 49r). 
Among Alguazir's Muslim sources, perhaps the most important are the creeds ( ${ }^{c}$ aqidas) of the famous $\mathrm{Ash}^{\mathrm{c}}$ arite theologian from Tlemcen, Muhammad b. Yūsuf al-Sanūsī (d. 895/1490). ${ }^{41}$ It was al-Sanūsī who, by introducing Aristotelian logic in the creed, gave a new impulse to an intellectual development of Ash ${ }^{\mathrm{c}}$ arite theology in the Maghrib (Hajji 1976, 2:82, 169; Olson 2020; El-Rouayheb 2015). The logical categories-necessary (wājib), impossible (mustahîl), and possible (jā'iz)—that al-Sanūsī employed in his creeds are taken up by Alguazir to point out the logical inconsistencies in the Apostolic Creed. Because of his a priori assumption of the truth of orthodox Islamic views, it is clear that not only is the Apostolic Creed attacked with the tools of Islamic logic, but also that Islamic dogma and theological tradition play an important role. In fact, it seems abundantly clear that many of the arguments found in Alguazir's work can be traced back to al-Sanūsī. Logic is the weapon chosen in this refutation of Christianity, aimed at the Christian allies of Alguazir's master, the sultan; thus, a moderate stance, rather than violent invective, was the most appropriate style of argumentation-a careful exercise in restraint that can be perceived throughout the text.

\section{The Comparisons Analysed}

What can we conclude based on the above comparative passages? In the first place, it is noteworthy that Alguazir's text exhibits the common quadripartite division of 'religions' in use in Europe at the time: Christians, Jews, Muslims and heathens (gentiles) (Smith 1998, 271). While he alludes to gentiles as a category, he never applies them to contemporary peoples, such as the indigenous inhabitants of the "New World," who were generally referred to in this way by Christian sources. Although, as we have mentioned, the text refers to "Christians" generally throughout, certain passages also differentiate between specific denominations, with a preference for Protestants-i.e. Lutherans, Calvinists, and Anabaptists-over Roman Catholics, since the former at least "deny the pope, the mass, the sacraments, the images, the confession and other things that the Roman church believes and considers truthful according to the followers of Saint Peter and the popes, whom they say will be condemned." 42 However, by the same token, the many divisions among the Christian denominations are taken as proof of Christianity's waywardness, since they are incapable of uniting behind one single version of their faith.

By contrast, Alguazir's rhetoric is harsher when aimed at the Jews, to whom he always appends the epithet "damned" (malditos), ${ }^{43}$ while Christians are simply described as erring or heretical. As for gentiles, they are sometimes deemed superior to Christians, as when he asserts that even they, who did not receive any prophets, could see that God is one: "this error [the Trinity] is so abominable that the false gentiles, in spite of having remained without the light of prophecy, are closer to the Truth through the understanding of reason, for they say

41 BNE Ms. 9074, f. 22v, mentioned by Aḥmad b. ' Abd Allāh in his Epistola as well, see Ben-Abdala (1705, 62).

42 "Otrossí los pecados que agora se haçen sson contra inffinito como lo ffue el primero, luego a cada pecado abía Dios de inbiar un hijo y era neçessario tener tantos como pecados cometen los hombres. Y el amor de Dios no se muestra d'essa manera, porque la jente chistiana que oi ay en el mundo no es de ziento uno, y aquellos pocos que ay es la maior parte de ellos de opiniones contrarias, como lo son calbinos luteranos, anabatistas, y en efecto, los que desmienten al Papa y offizios de la missa y sacramentos e ymágenes, confissiones, y lo demás que cree y tiene la yglessia rromana sigún los que siguen a san Pedro y a papas, y dizen ban condenados" (f. 42v-43v). See the "maldictos judíos" with their vision of Jesus and Mary, f. 35v. 
that if God were a sphere, His centre would be in all things, and His limits in no thing, in such a way that what the gentiles said is closer to the Truth than what the Christians say." 44

The "Christians" (obviously the Catholics, for here the Protestants are described as closer to the Muslims) are also compared to idolaters because of the cult of images. ${ }^{45}$ And though there is little invective, the author cannot help but describe as "abominable" those Christian beliefs which are particularly unpalatable to Muslims, such as the Eucharist or Transubstantiation. To say that God is in the wafer that Christians eat in the mass is, for Alguazir, the most horrid notion of all time; to believe in something so abominable and horrid as man eating God and drinking His blood is, in his view, beyond abhorrent. ${ }^{46}$ Here, the author takes the argument that many authors of Christian anti-Muslim polemical texts levelled against Islam-that Islam is irrational and devoid of any logical consistency-and turns it on its head. This polemical tactic is central to a number of Erasmian works, such as the Antialcorano by Bernardo Pérez de Chinchón, which assert that if Muslims would only accept reasonable arguments their conversion to Christianity would be an immediate and natural consequence. ${ }^{47}$

Alguazir's is a beautiful, well-crafted and concise text: his comparisons transmit an implicit but nonetheless very clear image of Islam as a religion based on reason and on the Unity of God, one that is pure, purified and devoid of adulterations that might pervert its single clear message, a religion that a believer can follow inside himself or by himself, with a Scripture that guides him in all aspects of life, and in which purity is fundamental. Through its comparison with Christianity, Islam emerges as a religion characterized by the core features of devotion and purity.

Although he may not have been the most knowledgeable scholar of Islamic theology in Morocco at the time, Alguazir probably knew more about Christian theology, and especially about Christian religious beliefs and customs, than many Muslims in Morocco, viz. Marrakesh, around him. Not only did he use Christian sources such as Aquinas's Summa, but also, though without mentioning him, Fray Luis de Granada's Introducción del símbolo de la fe, a fact that has remained unnoticed so far, or Alonso de Vascones. Alguazir uses the Símbolo abundantly and not to refute it, as he does with Vascones, but to describe the order of nature and how this wonderful order reflects God's creation and being. The contemplation of the small wonders and wisdom reflected in nature as described by Fray Luis find an echo and are adapted to an Islamic quest for interior spirituality. Nevertheless, it is not only Alguazir's knowledge of the written sources that can be perceived through the treatise, but also his personal knowledge of how Christians act during religious practices such as mass. During his life in Spain Alguazir would have been forced to participate in many Catholic rites, and he was conscious of the difference afforded to him by this knowledge of Christian life. Language constituted yet another advantage: Alguazir wrote that since most Christians do not know Arabic, they cannot read the books that criticize Christians or set out to defeat Christian doctrine. In his words:

44 "Es tan avominavle este herror que los falssos jentiles con no tener luz de profezía se açercaron más a la berdad con la raçón del entendimiento, pues dixeron que dios era una exph[e]ra, que su çentro estaba en todas las cosas y su çir ${ }^{[10 r]}$ cunferenzia en ninguna, de manera que lo que los jentiles dezían era más semejante a verdad que lo que los xptianos diçen" (f. 9v-10r).

45 "La missa o ssacrifizio de los chistianos es que juntándose en templo hombres y mujeres en uno, el saççerdote d'ellos se sube en un altar en al qual figuras de santos y de Chisto cruzificado, annsí como los idólatras hazían con sus hídolos."

46 "Otrosí que la ostia se la come el clérigo y diçe que Dios está en la ostia. Y después qu'el mundo es mundo, no se a visto mayor herror que decir que un hombre se come a Dios, caso por cierto, abominavle y espantosso" (f. 54v).

47 Wiegers (2001). Bernardo Pérez de Chinchón's Antialcorano was originally published in Valencia in 1532. In 2002 Francisco Pons Fuster published a modern edition (Alicante: Universidad de Alicante). 
this book may serve the purpose for which it was intended, namely to discover the truth of the highest word of the Unicity [of God ${ }^{48}$ ], for because of the error of the Trinity, innumerable souls go to hell, even though it is true that this task is not a suitable one for someone of my inferior intelligence, there being so many scholars among the Moors who have written about this subject. But, because these works are written in Arabic, which the Christians do not understand, I have ventured to do so, as I know Spanish, since I was educated among the Christians, and know the Law and traditions they follow.

This leads us to another question: what was the intended purpose of this work? In other words, why did Mawlāy Zaydān commission Alguazir to write it? There are at least two answers, which are not incompatible: there was a large number of Christian captives in Morocco at the time whom the authorities sought to convert, and also a large number of "renegades," Christians who had converted to Islam, motivated, amongst other things, by the desire to improve their life conditions, and whose knowledge of and faith in Islam might have needed reinforcement. On the other hand, exiled Moriscos had started arriving even before the general expulsion, and their adherence to Islam was at times seen as dubious. We know also of Christian missionaries active in Morocco, such as the Italian Dominican Constanzo Magni. In the 1590s he preached publicly to the captives of Marrakesh and exhorted renegades to return to Catholicism and to Christian lands, and to leave behind their Moroccan wives and children. Brother Constanzo helped those who wanted to do so, facilitating their passage through the Portuguese-held port of Mazagan (present-day El Jadida, Morocco), and spending a fortune on redeeming captives, before himself being thrown in prison in Marrakesh (Saldanha 1997, 312-16).

Finally, there is another possibility related precisely to the Latin version that we mentioned above, which constitutes the second text to be considered in this essay. It seems likely that the Spanish treatise authored by Alguazir was commissioned by the Moroccan sultan in order to serve as a polemic against Christianity intended for a Christian readership in the Netherlands. If this is so, the text must have been written between 1610 and 1612, already with the aim of having it translated into Latin.

\section{The Apología and its Adaptation in a Diplomatic Letter to Maurice of Orange and Manuel of Portugal}

Alguazir's text is basically the same as the one that was presented to Prince Maurice of Orange in the name of the Moroccan ambassador, sent to the Netherlands in 1612. The text originally given to the prince was probably written in Spanish, a language he read, and subsequently translated into Latin. However, of the manuscript presented to Maurice only the Latin translation has survived, but not the Spanish original. ${ }^{49}$ As mentioned above, the unique manuscript including the Latin translation later came into the possession of the English orientalist John Selden and was edited much later by Zacharias Grapius, a Lutheran theologian from Rostock. The Islamic arguments found in the text served as a source in Socinian (that is, anti-Trinitarian) polemics against orthodox Trinitarian Christianity in England in the seventeenth and early eighteenth centuries (Mulsow 2010; Champion 2010; Klein 2008).

48 A reference to the central Muslim doctrine of the tawhid.

49 Wiegers (1996, 121), idem Wiegers (2017b). On the Socinian use, see Mulsow (2010); Champion (2010). 
The embassy of Ahmmad b. ${ }^{c}$ Abd Allāh al-Haytī al-Marunī was not the first Moroccan embassy to the States General: between 1609 and 1613 plans were made on various occasions for an alliance between the Ottomans, Moroccans, and Dutch against the Spanish, and the Moriscos played a role every time. ${ }^{50}$ In 1613 , al-Hajarī, whom we mentioned in the introduction, personally discussed such an alliance with Maurice during a visit to The Hague, as he describes in his Supporter. ${ }^{51}$ Earlier, in 1610, plans for an alliance had been discussed in a diplomatic letter from the Ottoman general Khalil Pasha to the States General among considerations about the potential conclusion of a treaty.

Ahmad b. ${ }^{c}$ Abd Allāh al-Haytī al-Marunī was not, therefore, the first Moroccan ambassador to the Netherlands, but it is important to note that his mission culminated in the conclusion of the first Treaty of Friendship and the foundation of permanent $\mathrm{Sa}^{\mathrm{c}}$ did diplomatic representation in the Republic's capital, The Hague. The recent discovery of archival documents about the life of the Moroccan agents in the Republic, Joseph Pallache and his younger brother Samuel, which we have discussed elsewhere ${ }^{52}$ show that the Moroccan ambassador Ahmad b. ${ }^{\mathrm{c}}$ Abd Allāh was received with all the pomp accorded to foreign ambassadors in The Hague. In 1610, the ambassador and his entourage made a tour around the Lange Voorhout in coaches, and a banquet was offered at the Binnenhof, probably in the parts of the building reserved for the Stadhouder, at the time of Maurice.

After his return to Morocco, the ambassador sent Alguazir's text to Maurice, presenting it as his own and adding a preface addressing his interlocutors. This preface begins with a mention of the splendid banquet (splendida mensa) given in 1610 during his diplomatic mission to The Hague (Ben-Abdala 1705, 8). In the course of this banquet, Maurice, a Protestant, and his Catholic brother-in-law, Prince Manuel of Portugal (1568-1638), married to the Protestant Emilia, the third and youngest daughter of Prince William of Orange (one of Maurice's sisters, 1569-1629), had questioned the ambassador about the Muslim view of Jesus. Ahmad b. ${ }^{c}$ Abd Allāh had had two reasons, he explains to Maurice in his letter, to answer now (in writing) rather than on that occasion. ${ }^{53}$ First of all, the moment had not been suitable. An important question like that could not be answered in a satisfactory way during a banquet (inter prandendum). Secondly, he had felt that he first needed to consult sources such as Qur'ānic commentaries (interpretatio sancti Alcorani), works dealing with the Unity (the tawhìd, i.e. works of Islamic theology), the Sacred Scripture (Sacra Scriptura, i.e. the Qur'ãn), and the Gospels (Evangelia) (Ben-Abdala 1705, 14-17). In the preface, Aḥmad b. ${ }^{\mathrm{c}}$ Abd Allāh also briefly discusses not only the relations between religions and religious doctrine, but also deals with matters of politics. Even though he considers Islam to be generally superior, he makes an exception with respect to matters of politics, in which he acknowledges the superiority of his Christian counterparts in economic and military aspects. He immediately adds, however, that there is no doubt in his mind that the Muslims will improve, and that matters of state are of secondary importance to the well-being of individuals, which first of all depends on the soundness of their religious beliefs. He also announces passages in the main text which will refer to the political activities of Prince Maurice and Manuel of Portugal, both present at

$50 \quad$ See the Hebrew translation (forthcoming, Jerusalem: Magnes Press) of L'uomo dei tre mondi. Storia di Samuel Pallache, ebreo marocchino nell'Europa del Seicento García-Arenal and Wiegers (2013), translated into Dutch as Samuel Pallache. Koopman, kaper en diplomaat tussen Marrakesh en Amsterdam, García-Arenal and Wiegers (2014a).

51 Van Koningsveld, Samarrai, and Wiegers (2015, chap. 11); about the Netherlands, English text, 219-36.

52 See the publication mentioned in note 65.

53 "causae enim duae me moverunt cur nunc potius, qvam tunc respondere maluerim." 
the dinner in 1610, regarding certain religious affairs. ${ }^{54}$ In this way, he stipulates a clear relationship between the discussions with the Princes and the content of the treatise. There is an unequivocal claim of authorship when the ambassador speaks about his attempts to address the Princes in a learned style. He shows a keen awareness of the delicacy of his undertaking, and begs their pardon at the end of the prologue for possibly having expressed himself too freely.

The most noteworthy changes in content between the preface and the Latin text are to be found in the fragments following the passage in which Muhammad is referred to as the Messiah. ${ }^{55}$ The Latin text pursues the argument by elaborating on the figure of the Paraclete, who according to the New Testament is an intermediary whose coming was promised by Jesus to his disciples, but who according to Muslim polemicists should be interpreted as a reference to the future coming of the Prophet Muhammad. This is immediately followed by a summary of the reasons for refuting articles six and seven. Then, there is a transition to memories of his journey through Germany, and of how he saw Manuel, the Prince of Portugal, protecting the Catholic mass there. This gives cause for a discussion of the mass, including the host (p. 124), which faithfully follows Alguazir (Alguazir's chapters 5 and 6 being dealt with together), then of marriage for priests (p. 129), and finally of confession (p. 130).

It is interesting to note that Aḥmad b. 'Abd Allāh's letter also includes a passage on free will, a topic that certainly must have interested Prince Maurice, the Lord of Aguila, the Catholic Manuel, and the court pastor Johannes Wtenbogaert, also known as "The Pope of Holland" (Heering 2019). The country was at the time torn apart by a theological dispute about predestination and free will, which brought consequences for the relations between church and state. Religious debates and disputes were frequent in the Dutch Republic, as well as in other parts of Europe during those years, though they were not possible in Morocco, or in Spain, the country of origin of Alguazir, of the ambassador ${ }^{c} A b d$ Allāh and of al-Hajarī. Al-Hajarī describes several religious disputes that he sustained in the Republic and in France. In France, while discussing with a French counterpart, al-Hajarī told him:

You should know that I am the interpreter of the sultan of Marrakesh. He who occupies that post must study the sciences, as well as the books of Muslims and Christians in order to know what he is saying in translating in the court of the sultan. But when I am in the presence of the scholars of our own religion, I am not able to talk about religious sciences. ${ }^{56}$

We must take into account the social and political context and the interest of the Moroccan sultans in establishing commercial treaties with the Dutch Republic. Therefore, the polemical text produced by Alguazir and adapted by Ahmmad b. ${ }^{\mathrm{c}}$ Abd Allāh had to navigate between Scylla and Charybdis: elucidating the Islamic point of view in religiosis, as well as the Moroccan partnership in what was probably conceived of as a promising alliance between two sworn enemies of Spain: the Low Countries and Morocco. For this purpose, it had to be written in a language which could be understood by its intended audience. Spanish was a language with which Maurice was familiar, and in a broader context it was also the language used at the time for diplomacy.

54 Ben-Abdala (1705, 32): “Addam praeterea in fine, quae a Principe Portugalliae (in Civitatibus et locis Pontificiis Germaniae, per quas transibamus) fieri audivi, etiam qvid sit in causa, qvare Presbyteri et sacerdotes Pontificiorum non ducant Uxores."

56 Van Koningsveld, Al-Samarrai, and Wiegers (2015, English translation 54-55). 
The second element of the text which is to be found in the Selden manuscript, but is completely absent from Alguazir's text, is an intriguing colophon at the very end of the treatise, which reads as follows:

If anything [in this letter] has been said in too outspoken a manner, then I pray with all my heart that my audacity be forgiven, as your excellencies are wont to do because of your generosity and goodness, and I would think that I had failed to accomplish my task if I had not answered such an important question posed to me by such important Princes. And if I did not do so earlier, it was only because I was unable to find a trustworthy messenger, ${ }^{57}$ like the present bearer, who at the same time will hand a transcript to the Lord of Aguila, who, I hope, will also reply [to my work], in spite of my rough pen. ${ }^{58}$ And herewith I conclude this treatise, again asking for forgiveness, which (I doubt not) has already been granted to me by such fine and great kings as you, my lords. And I pray to God for you, I, the aforesaid Ahmmad b. ${ }^{\mathrm{c}} \mathrm{Abd}$ Allāh, of Cantabrian origin and a member of the Marrón family, I, who wish you all sorts of happiness, greatness, power, and life. Sent from Marrakesh, at the beginning of the year 1021 of the Hijra of our lord Muhammad, the salvation and the blessing of God be with him, and with all other Prophets and Saints. Amen. Amen. ${ }^{59}$

This is the context of the text presented by Ahmad b. ${ }^{c}$ Abd Allāh al-Haytī al-Marunī. We see that the text is dated at the beginning of $1021 \mathrm{AH}$, which roughly coincides with March and April 1612. Comparison shows that the Latin text, which as we will see was printed in $1705,{ }^{60}$ is a faithful translation of the first seven chapters of Muhamad Alguazir's polemic. Chapter

57 The Latin word lator used here is very unusual. A more common term would be cursor or nuntius.

58 The person mentioned here as the Lord of Aguila was an enigmatic figure known by various names, among them Enriques de Aguila and Francisco de Gamboa. Like Aḥmad b. ${ }^{c}$ Abd Allāh he was probably from Northern Spain (see De Castries, ed Les sources inédites de l'histoire du Maroc. Première série-dynastie sac dienne. Première série, Pays-Bas, I, p. 533) but, unlike the former, Aguila had become a Protestant after he left Spain in about 1604. From Spain he went to the Netherlands, where he married into the well-known family of high standing called Van Lynden. In 1610 he offered his services to the States General to negotiate with the Moroccan Sultan Zaydān that a loan the latter granted to the States might be converted into a gift. According to archival documents, the States mistrusted him and decided not to grant him an official mission, but merely to write a letter of introduction for him. Even the letter was never written. Moreover, informed about the seizure of Larache (1610), Aguila apparently changed his mind and decided not to go to Morocco. An Englishman, Ralph Winwood, suggests this much in a letter written at The Hague, 29 December 1610: "Here is a Spaniard maried in Guelderland, who calleth himself d'Agula. He presented his service of the States, to be employed to the King of Morocco, in exchange of the dowble ambassage which hath come from him; but the late newes of the surprise of Larache hath advised him to change his mynde; dowbting of the surety of his passage, and of his treatment (being banished out of Spayne) if his ill fortune should be to be taken," see De Castries, ed Les sources inédites de l'histoire du Maroc. Première série-dynastie sac dienne. Archives et Bibliothèques d'Angleterre, II, p. 458).

59 Dated on p. 136: "si igitur qvidqvam liberius dictum est, obnixe oro ut huic meae audaciae ignoscatur, ut benignitate et summae virtuti Ecellentiarum Vestrarum mos est, neque videbatur fecisse satis meo officio, nisi tantae interrogationi, et tantis Principibus responderetur. Qvod si antehac factum non est, ideo solum est, qvia non invenirem latorem fidum ut hic est, qvi una dabit Domino Aqvilae aliam copiam, qvem spero etiam responsurum meo rudi stylo. Et ita imponam huic scripto finem, petens iterum veniam, qvam mihi concessam non dubito, a talibus et tantis Principibus Dominis meis, pro qvibus Deum orat omnipotentem qvi omnem felicitatem, magnitudinem, potentiam et vitam eis cupit supra nominatus Ahmet Benaudala, natione Cantaber et familia Marron. Dat. Marrochii in principio anni mille et viginti unum del [sic, here the Spanish word 'del'—of the-seems to have been mistakenly maintained; MGA and GW] Haxara Domini nostri Mahumeti, salus et Gloria DEI sit supra eum, et supra omnes prophetas alios, et sanctos, amen, amen.” This formula at the end is a common way of concluding a text in the Islamic tradition.

60 From this point on we will follow Grapius's edition, Mohammedani Epistola Theologica de Articulis Quibusdam Fidei Ben-Abdala (Ben-Abdala 1705), alongside the Selden manuscript. 
eight is not included in the Latin translation, which makes sense given that its focus is no longer on the refutation of the Apostolic Creed and on the rituals based on it, but rather on the Islamic doctrine of the Divine Attributes (Ar. al-Sifāt) and its incompatibility with Christian dogma. For that reason, it seems to address an Islamic rather than a Christian readership, and is of less interest to the latter than the first seven chapters.

Although the Latin version is a faithful translation, there are a number of interesting differences. ${ }^{61}$ In particular, one can discern a certain shift in tone and in terminology that we will now analyse. The Latin version of Muhamad Alguazir's polemic skilfully insinuates the close similarities between Protestantism and Islam, thus providing an interesting counterpart to "Calvinoturcism." ${ }^{2}$ Whereas the Spanish text speaks about "Christians," the Latin version leaves no doubt that it is in fact the Church of Rome that is under attack. We may compare, for example, the Latin text to the Spanish in BNE Ms. 9074: "With respect to the prohibition of the marriage of clerics, this is against God's law," ${ }^{63}$ and the following passage in the Latin text, which reads, in translation, "In the Papist religion no priest is allowed to marry." general, where Alguazir's text reads "Christians" (Cristianos), the Latin text reads "supporters of the Papacy" or "Papists" (Pontificii), clearly referring to the followers of the Catholic Church. It is unclear whether this change was introduced by the translator of the Spanish original, or whether it was in the original (lost) version sent to Maurice and Manuel. If this was indeed the case, the polemic is exclusively directed against Roman Catholicism, rather than against Christianity in general, Protestantism included. Since this change shielded the Protestants from many of the text's accusations, it may be understood as an attempt to stress points of view that were common to Islam and Protestantism. Hence, we may see it as a Muslim adaptation of "Calvinoturcism," stressing the closeness of Catholicism to paganism in order to discredit it, which we might refer to as 'paganopapism.' Another alteration seems to suggest that we may indeed be dealing with 'paganopapism': where Alguazir speaks about the distinction between Muslims and Christians because of their different dogmas with respect to Jesus's death, the Latin translation speaks about the distinction between Protestants and the supporters of the Papacy due to the former's denial of papal authority. ${ }^{65}$

At the same time, throughout the Latin text we can see that negative qualifiers in the Alguazir manuscript have been softened. For instance, absurda is to be found instead of abominable. The comparisons with the heathen or pagan gentiles are softened by using instead the term philosophos. And so, for example, regarding the text by Alguazir quoted above (f. 9v-10r):

61 Compare, for example, the beginning the letter itself, Ben-Abdala $(1705,33)$, and the beginning of the introduction in Madrid, BNE Ms. 9074, f. 6r-v. The Latin text reads: "Articuli fidei sunt qvatuordecim. Septem primi pertinent divinitati, septem reliqvi humanitati. Qvatvuor primi sunt isti. Primvs credere in unum solum DEUM 2. Credere eum esse Patrem 3. Credere eum esse Filium 4. Credere eum esse Spiritum Sanctum. hi qvatuor ita sibi invicem contradicunt, ut vix sit opus refutatione, et certe hic error de trinitate maximus est omnium. Nullus enim humanus intellectus potest percipere vel etiam intelligere, unum et idem esse Patrem, Filium et Spiritum Sanctum in unicâ solâ essentiâ et uno eodem tempore." See Muhamad Alguazir (BNE Ms. 9074): "Capítulo primero de la contradizión de los quatro artículos primeros que son creher en un solo Dios todopoderosso, el segundo creher qu'es padre, el terçero creher qu'es hijo, el quatro qu'es espírito santo, son estos quatro atributos tan contrarios en si que cassi no tienen nezesidad de contradizion pues ellos mismos se contradizen haçiendo que uno sea padre y ese mismo sea hijo y ese mismo sea espiritu santo, en un tiempo y en una exsençia."

62 On Calvinoturcism, see the seminal article by Nicolette Mout (1978).

63 f. 52r: "en cuanto al no cassarse los clerigos es al contrario de la ley de Dios [...]"

64 Ben-Abdala $(1705,129)$ : "in pontificia religione nullus sacerdos potest ducere uxorem."

65 "y los demás que cree y tiene la yglessia romana sigún los que siguen a San Pedro y a Papas y dizen ban condenados, y siendo anssí, qué amor hobró Dios con la jente y, si por no creher su muerte ¿ban al ynfierno?" Latin: "Si hoc esset verum, unde apparet amor Dei, si sola ea causa (qvia non credunt Pontifici, aut ejus Decretis) damnarentur” (BNE Ms. 9074, f. 43r; see Wadham Ms., f. 48v). 
Es tan avominavle este herror que los falssos jentiles con no tener luz de profezía se açercaron más a la berdad con la raçón del entendimiento, pues dixeron que dios era una exph[e]ra, que su çentro estaba en todas las cosas y su çircunferenzia en ninguna, de manera que lo que los jentiles dezían era más semejante a verdad que lo que los xptianos diçen.

In the Latin translation it is rendered as:

Reuera miror philosophos et gentes sine lumine ullo prophetiae solo lumine naturali propinquiores esse ueritati Christianis; dixerunt enim Deum esse unicam e se sphaeram, cuius centrum ubique in omnibus rebus est, eius uero circumferentia nullibi, deinde falsum est, solem esse unum et tres res, cum Sol sit corpus habens calorem, splendorem, motum, praesentiam et absentiam, et alia accidentia ut caetera corpora.

In the Latin text we perceive a subtle elimination, in general, of direct references to Christians, thereby underscoring the argument against the Trinity and in defence of the Unity of God.

Ms. Arch. Selden. B 8

Mirandum igitur est eos Christum et Spiritum sanctum uocare Deum, qui possunt iuxta ipsorum simile separari ab essentia patris manente Deo. Hinc possent etiam alia infinita absurda colligi. Aiunt praeterea Trinitatem referre animam rationalem quae cum sit una, constat tribus: memoria, intellectu, uoluntate.

Haec etiam similitudo est nulla, quia memoria, intellectus ${ }^{66}$, uoluntas non sunt tres animae, sed tres potentiae animae. Sed personae Trinitatis (ut ipsi dicunt) omnes aequaliter sunt perfecte Deus, et sunt una et eadem res, potentiae uero animae non ita, quia quod conuenit essentia non potest separari ab ea, sed potest dari anima sine intellectu et memoria, ut apparet in innocentibus, ergo memoria et intellectus non sunt anima.
BNE Ms. 9074

Por cierto qu'es buen Dios el que faltando no haçe falta. Dios nos libre de tal error. $Y$ diçen y alegan los chistianos que la trinidad es como el ${ }^{[11 \mathrm{v}]}$ alma, que son tres cossas y es una: tiene memoria, entendimiento y boluntad, y anssí la trinidad son padre y hijo y espíritu sancto $\mathrm{y}$ es uno solo.

A los quales respondemos, qu'estas tres cossas son potenzias del alma y cada una d'ellas no es alma sino potenzias suias. $Y$ ellos diçen que las tres perssonas de la trinidad son yguales, y cada una d'ellas es Dios cumplido, y son una misma cossa. $Y$ estas tres cossas del alma, memoria, entendimiento y boluntad, no ${ }^{[12 r]}$ no son una cossa, porque lo que conviene a la exsenzia no puede ser sin ella, y pues puede aver alma sin entendimiento, como lo vemos en los locos, claro es no ser la memoria el alma ni el entendimiento. 
Ms. Arch. Selden. B 8

BNE Ms. 9074

Et ita similitudo omnino nihil probat, quia potius Luego este exemplo les desvarata inde sequeretur Christum Dominum nostrum Iesum, neque spiritum sanctum esse Deum, cum possit dari Deus sine iis, sicut anima sine memoria et intellectu. su trinidad y diremos Chisto no es Dios pues puede aver Dios sin Chisto anssí como puede haver alma sin entendimiento.

\section{The Grapius Edition of the Diplomatic Letter and its Historical Context}

We will now turn to the printed Latin text of Alguazir and its trajectory in Northern Europe. The story of the Latin manuscript was far from over when it entered the Bodleian Library's holdings, as we will discuss now turning to Gottfried Christian Goetze (d. 1724). Gottfried Goetz was a judge and librarian born in Leipzig (we do not know exactly when), where he read law. In 1697, he embarked, like so many others of his time, on a Grand Tour, which brought him to England, possibly via the Netherlands. There, while working in the Bodleian Library, he copied the Ahmad b. ${ }^{c}$ Abd Allāh text from the Selden manuscript (Klein 2008, 41). Goetze describes the Selden manuscript as very faulty. The lawyer's interest in the text sprang from Europe's concern at the time with the scriptural foundations of Trinitarianism. Martin Mulsow, for example, discusses the contacts between Noël Aubert de Versé (1642/5-1714) and a Moroccan envoy to England aiming at a Unitarian alliance against the Trinitarian Christians, but there was also an interest among theologians and orientalists in Leipzig, though mainly from a Lutheran, anti-Trinitarian perspective (Mulsow 2010). Klein thinks that it may have been Goetze's mentors in Leipzig who drew his attention to the anti-Trinitarian text included in the Selden manuscript, which he copied out (Klein 2008, 43). Through a brother of Goetze, the transcription came into the hands of Zacharias Grapius (1671-1712), who had just been appointed professor of Lutheran theology at the University of Rostock. Grapius published the Latin text without delay. His interest in the matter also sprang from his theological inquiries into the scriptural foundations of the Trinity. Grapius defended a Lutheran Trinitarian view against the Socinians and others in the numerous disputations in which he was involved.

The Latin version printed by Grapius is heavily annotated: Although the emphasis of the text had already shifted, due to the influence of the Lutheran theologians, to underscore its anti-Trinitarianism and anti-Catholicism, the scholars that worked on these glosses and notes remained aware of the Islamic content and Qur'ānic references of Alguazir's text. ${ }^{67}$

66 Ms. "intellus."

67 Viris de uniuerso orbe literario meritissimis, et quotidie adhuc singulariter merentibus. Dnn. Fautoribus ac amicis suis omni amoris, et honoris cultu maxime deuenerandis, plagulas hasce, quas gratiae ipsorum, ac indefesso in rem literariam studio debet, nunc excellentissimis ipsorum nominibus consecratas summa cum mentis gratitudine reddit, easque cum uoto omnigenae prosperitatis, maiorisque uirtutum, ac meritorum famae, necnon cum ulteriori commendatione sui enixissima offert tantorum nominum cultor ingenuus ac deuotus Z. Grapius Rostochiensis.

[3] Nomina clarissimorum dnn. Disputantium

Dn. Christianus Henricus Von Elswich Rendesburgo-Holsatus.

Dn. Iohan $<$ nus $>$ Herman $<$ us $>$ Von Elswich Rendesb $<$ urgo $>$-Hols $<$ atus $>$.

Dn. Bernhardus Raupach, Tundera Cimber.

Dn. Wilhelmus Schaller, Witteburgo-Megapol. 
An extremely thorough task of annotation and erudition was carried out by the group of scholars that worked on the edition of the Latin text. For them, it was also interesting from an orientalist point of view: the list of names that participated in the edition is indicative of the interest it aroused in such circles. The glosses of the Qur'ānic material in the text often refer to the work of the famous Swiss orientalist Johann Heinrich Hottinger (1620-1667), professor of Oriental languages and biblical criticism at the Universities of Heidelberg and then of Leiden, and the author of a polemical work against Roman Catholicism. Thus, the threads of Orientalist knowledge, biblical studies, and religious polemics become increasingly intertwined with the text of Alguazir (Loop 2013).

\section{Alguazir's Apología and the Morisco Diaspora: Ibrahim Taybili and his Contradictión de los catorce artículos de la fe Cristiana}

The third version of Alguazir's Apología was written by yet another exiled Morisco, Ibrahim Taybili, who made a versification of it in Tunisia. Ibrahim Taybili was a Morisco cloth merchant from Toledo, where he had lived by the name of Juan Pérez. He settled in Tunis after the general Expulsion of the Moriscos in 1610 and later, after retiring from business, he chose to lead a peaceful life in the Tunisian village of Testour, where many Moriscos had settled under the protection of the Ottoman authorities. In 1037/1628, he composed a treatise, as he himself says, at the behest of Yusuf Dey and under the protection of the Sharîf ${ }^{c}$ Ali al-Niwãlī, to whom the book is dedicated. ${ }^{68}$ The aim of this treatise, as stated by Taybili in his preface, was to provide the Moriscos with sound doctrinal material in Spanish, which continued to be the community's primary language ${ }^{69}$ He decided to render it in verse so that it could be easily memorized. ${ }^{70}$ In his preface he speaks of the quiet and solitary life he leads in the Tunisian countryside, recalling and reflecting upon his life in the land where he was born and bred, and where he was raised in the Catholic faith. ${ }^{71}$ It was in this retirement, it seems (we are

\footnotetext{
Dn. Christianus Witscher, Gustrov-Megapolit.

Dn. Johan. Frieder. Hinck, Roebela-Megapolit.

Dn. Joach. Petr. Rumpf, Demmino-Pomeran.

Dn. Bartholdus Prüssing, Warena-Mecklenb.

Dn. Joach. Mildahn, Zud-Rugiano-Pomeran.

Dn. Joach. Fried. Queitsch / Falcoburg? -Marchic.

Dn. Anton. Boldewin. Kling / Hadersleb? -Holsat.

Dn. Nicolaus Wenthin, Anclamo-Pomeran.

Dn. Joan. Nicol. Quistorpius, Rostoch. Meckl.

Dn. Bartholomaeus Dipkin, Riga-Livonus.

Dn. Jacob. Christoph Sandt /Durlaco-Badensis.

Dn. Andreas Westphal, Anclam-Pomeran.

Dn. Joan. Guilielm Weinman /Mitav-Curon.

Dn. Bartholomaeus Wybers, Riga-Livonus.
}

68 See on him and his place in Morisco life in Tunis, Wiegers (2014).

69 In his translation of Qadi Iyād,'s Kitāb al-Shifā', which he completed in 1634, al-Hajarī says that he had translated the book into Spanish because "God, our Lord, says in the Quran: 'We never sent any messenger but with the speech of his people' and I know that the majority of the Spanish Andalusians know the Romance language better"; van Koningsveld, Al-Samarrai, and Wiegers $(2015,60)$. See on the significance of the works of Qadi Iyād among the Moriscos, Bernabé Pons (1998).

70 Taybili's work is preserved in one single manuscript at the Biblioteca Casanatense di Roma (BCR, Ms. 1976). It was edited by Bernabé Pons (1988). The quotations we give here stem from a new edition Bernabé is preparing. We wish to acknowledge his generosity in putting this new edition at our disposal prior to publication.

71 "trayendo a la memoria aquella bida pasada donde fui naçido [3r] y criado y considerando y acordándome de aquella bana ydolatría, de aquella yronía y çeguedad tan grande de que la alta y ynmensa probidençia 
not told how and under which circumstances), that Alguazir's work came into his hands and, seeking to spend the time in a pursuit that was at once pleasant ("çelosso de gastar el tiempo en algún entrenimiento") as well as virtuous in religious terms, he decided to set the text to verse. It becomes clear upon comparison that Taybili rather faithfully follows all parts of Alguazir's text, consisting of eight chapters, as in both Spanish manuscripts.

After the prologue, in the first of the work's thirteen cantos, ${ }^{72}$ Taybili thanks God for liberating him from heresy and compares himself to Daniel, who was saved by God from the fire. In this narrative he confesses that he had lived in blindness and error during his previous life in Spain, and that he took part in the Christian rituals and ceremonies. ${ }^{73}$ After comparing himself briefly to Daniel, the author alludes to other biblical and Qur'ānic figures and prophets (such as Ahasueros, Mordechai, Moses and Absalom), stories of fortune and adversity, all examples of God's will and intervention. These passages are a prelude to what Taybili narrates subsequently, the story of the Moriscos, expelled by the king of Spain, Philip III, between 1609 and 1614. Here, Philip is but an instrument in God's hands to lead Moriscos to freedom from Christianity. ${ }^{74}$ The story of the Moriscos is told in a messianic and providentialist vein, punctuated by the happy acceptance of their fate. ${ }^{75}$

Taybili was a cultivated man, knowledgeable in Spanish literature and culture in general, including classical literature, for which he had a clear taste and inclination. References to Martial and Horace appear in the prologue, as do allusions to the stories of the Sibyl. The prose in his prologue is rich, intricate, and baroque. In his Contradictión, he invokes the muse Thalia, quotes Pliny, and makes use, as we have seen, of Biblical stories. He is also well informed about Spanish theatre and even painting, and this overall knowledge and appreciation appear abundantly in his other works that have been attributed to him. Taybili, then, was deeply embedded in the culture of the cultivated Spaniard of his time. ${ }^{76}$

As Teresa Soto has shown, most of the additions Taybili includes in his Contradiction that differ from Alguazir's text (foreword, prologue, epilogue, "Canto primero" and opening and closing stanzas) are interlaced with verses drawn from the work by the Spanish religious poet José de Valdivielso, who wrote an account in verse of the life of Saint Joseph that was extremely popular in Toledo at the beginning of the seventeenth century (Soto 2019). Taybili creates a polemical discourse whose fiercely anti-Christian message is not at odds with the

de Dios nos sacó, y habiendo bisto un libro que a mis manos bino cuyo autor fue Muhamad Alguazir, beçino que fue de Pastrana y al presente de la ynsigne çiudad de Marruecos, en que contradiçe la falsa ley cristiana no dejando qué deçir en su agradable prosa, pues çeloso de gastar el tienpo en algún entretenimiento, y por no enplear el tienpo y pluma en lo profano y sin probecho, enpeçé esta obra, mudando el urdinario estilo de la prosa en umilde berso, con más faltas que yo quisiera, que no es posible no tenerlas ni que cuando le faltaran, faltara quien se las ponga."

72 As is well known, the Muslim creed written by the Mudejar faqih Iça de Gebir of Segovia consisted of thirteen articles as well.

73 [18 r] "Como a Daniel del exçesibo fuego,/conozco, inmenso Dios, me habéys librado,/y que torpe nací, del todo çiego,/entre los ydólatras engendrado./Entre ellos me crié; la ley de juego/me tubo un tienpo en sí como encantado,/siguiendo sus mentiras y herexías,/su misa y sacramentos hartos días."

74 "Ynmenso Dios que nos habéys librado/de la herética ley de los cristianos/y a la dibina ley encaminado,/do buestros atributos soberanos,/confesamos, Señor, lo que os he dado,/que es la Unidad que niegan los paganos,/que el poder y el querer en bos se ençierra,/en cuanto conprehende çielo y tierras. f. 19r. Felipho, rey de España/ se dispone/pensando descubrir su fortaleça,/y es que por instrumento Dios le pone/ de su infalible y inmortal çerteça/ hordena dios que el bando se pregone/ que salgan los moriscos con prestezça/ y viene a ser camino esta salida/ para que en libertad passen la vida" (fol 19v). See, on this discourse, Wiegers (2017a).

76 Other works by Taybili or attributed to him are the Tratado de los dos caminos and several other Spanishlanguage religious writings. See, on him and on this text, also Oliver Asín (1933) and Colominas Aparicio (forthcoming). See also Bernabé Pons (2017). 
extensive use of Christian material; indeed, Alguazir had already done the same with his use of Fray Luis de Granada, as mentioned above. Taybili does not acknowledge these borrowings, nor does his rejection of the Christian religion extend to the whole of Spanish culture: he treats Spanish culture as his own and tries to tease out, for himself and his kin, the illicit religious aspects. Taybili's work is therefore at once much more rooted in Christian Spanish culture (he seems to be more well-versed in baroque-era Spanish culture than Alguazir), and at the same time much more weighted against Christianity than Alguazir's. His repudiation is violent, his invective constant. Occasionally it seems that he is fighting against a part of himself, a part of his audience. Christianity is a false and barbarous law, it is heretical, and full of insolence. Christians are obstinate and blind, incapable of recognizing the truth. Jews are vilified ("El bil judío que es por Dios maldito," f. 35 v), but Christians are blind and lost, their popes having led them into error and falseness in a venture guided by the devil. ${ }^{77} \mathrm{He}$ aims at destroying and annihilating their beliefs, ${ }^{78}$ but also at creating a strong revulsion against Christians, whose beliefs and behaviours are depicted as being outrageous. It is not only that heathens (gentiles) are better-he enumerates the Scythians, Troglodytes, Lotus-Eaters, and other infernal nations living in darkness as having erred less than the Christians, and having acted less brazenly against God. ${ }^{79}$ There is no nation that defies God in such a way as the Christians; none is so blind and ignorant ("no ay naçión contra dios tan atrebida/que la Cristiana infiel desconoçida"). Unlike Alguazir, he does number among the gentiles the peoples of the New World, specifically those who live along the Marañon river, in the lands where clove and ginger grow. ${ }^{80}$

While Taybili faithfully follows Alguazir's work, he differs from him not only in his degree of invective but also by enlarging or widening the scope of comparison, including longer and more detailed descriptions of Christians' behaviour. Taybili's adaptation of Alguazir's chapter on the mass is a good example. ${ }^{81}$ Not only does Taybili dedicate a great deal of space to the mass, much more than in the original by Alguazir, but he also limits the description of the Muslim prayer, in comparative terms, to its Christian equivalent. He justifies this choice by saying that he is "not going to say what is well known," or "not going to say or to insist too much." It is interesting to note that this part of the work contains a series of detailed descriptions both of the places of worship and of the rituals carried out there: the font with the holy water placed at the entrance of the church and the words to say when dipping one's fingers in it, the altar, the space with benches and pews where men and women are

77 As an example, f. 26v, "sino por el herexe que obstinado/çiego y encaminado del demonio/arma y cree un falso testimonio"; f. 35v, "en ber la ley tan falsa de que traban,/estos cristianos çiegos y perdidos/por los papas herexes fementidos"; f. 21v, "Ah, pueblo çiego,/ qué mal fundado ba vuestro proceso/pues abrazays las cosas ynpusible/ y negais las verdades infalibles!"

78 As he explicitly states in the prologue, referring to his own work as: "esta humilde obra donde hallarás deshecha y aniquilada la falsa ley cristiana y su artifiçiosa trinidad" (f. 15r).

79 "Entre los arimaspos y los sçitas,/bárbaros en bibir y en su gobierno,/lothophagos, cíclopes, trogloditas,/naçiones cuya ystançia es el ynfierno,/sin otras mil naçiones ynfinitas,/no conoçieron al que es Dios eterno,/y con tener luz menos herraron/que los cristianos en lo que fundaron" (f. 19v).

80 "Dios nos libre/de tal herror de aqueste herexe bando,/pues desde el Maranón, do corre él libre,/no ay mayor çeguedad, y buelta dando/hasta a donde naçe el clabo y ajenjibre, /la canela, pimienta y nuez moscada, no ay gente más perdida y más herrada" (f. 23r).

81 "Es la misa de alba la primera/ que es el amaneçer de madrugada; luego misa mayor, y la postrera. La mayor, en efeto, es çelebrada/ con música, con órganos y çera, y será a las diez horas comenzada, do ban entrando y ban tomando asientos, tratando solamente en banos cuentos. Lo primero que tienen en la entrada/ es una agua que diçen sser bendita, que con los cuatro dedos es tocada, y tocando una cruz diçe contrita/ la gente, ya después de santiguada: esta agua, señor, que es tan bendita, me sea espiritual salud y bida, y mi rogaria çepta y conçedida"; analysed in $(2019,346)$. 
mixed together, how the priest comes out of the sacristy and reads "the Epistle and Gospel" before "eating God and drinking His blood." Taybili describes the different services and their schedules, as well as the organ music that accompanies them. ${ }^{82}$ In this particular passage, he describes the beauty of delectable music, which, heard on a clear and serene night, makes all things appeal to the senses. But the celebrations usher in dancing, fires, noise, and rowdiness, while by contrast, it is implied, Islam is peaceful, ethically superior, calm, pure, and silent. The passages on music and other similar aspects in this canto seem to mark a difference not only with Christians as an external other, but, on an internal and personal level, with a part of the author's former, or perhaps current, self. It is as if Taybili is somehow telling the story of himself and of his previous life in retrospect ${ }^{83}$-and maybe also the life of his audience, in whom he wants to instill a sense of repudiation toward the Christian elements of their upbringing.

Each of these detailed descriptions leads up to unequivocal rejection and derision. ${ }^{84}$ Taybili describes at length the Christians' lack of true devotion, how they go to mass in a filthy state, wearing dirty clothes and without bathing, and with shoes they have dragged through the gutter; how dogs enter the church and relieve themselves there, and the smells they produce. ${ }^{85}$ He also likens the atmosphere of the church to that of the marketplace, where people talk, and where men cast leering glances at women since the sexes are allowed to intermingle in the pews. ${ }^{86}$ Their priests, who are not allowed to marry, are as a consequence lascivious, adulterous sodomites who have illegitimate children with nuns, whose convents are dens of iniquity. ${ }^{87}$ On the other hand, in Muslim communities the clothes of the believers are clean and simple, men and women are arranged in separate spaces, and all can pray without the need of a priest. All is purity in Islam, while in Christianity all is filth. Thus, Taybili's is a text of total repudiation, of separating us from them, of casting them, the other, as scandalous, with the aim of arousing revulsion and total repudiation.

There is another interesting passage in Taybili that does not come from Alguazir. In the treatises written against the Moriscos before the Expulsion, Christians often accused them of being ignorant of their own religion. Taybili retaliates by accusing Christians not only of

82 "Sus tenplos, sus yglesias sienpre llenas/ de músicas al gusto, deleytables, órganos muy gustosos y otras buenas chirimías, cornetas agradables, en las noches más claras y serenas. Sus fiestas son con fuegos admirables, no çelebran ni ay fiestas do no ay fuego, danzas, ruydo y desasosiego" (f. 67 r).

83 See, on the boundaries between reform and orthodox Jews on the basis of the use of the organ, prohibited by the one and allowed by the other in Germany during the nineteenth and early twentieth century, Krech (2017). In addition to a psychological interpretation we also have to take into account the ideological aspect: Taybili belonged to the Morisco elite in Tunisia, which aimed to an ideology suited to their pursuit of power and influence; see, for example, Wiegers (2017a).

84 "El cual es diferente, como bemos,/en los tenplos de moros cual se sabe,/todo lo más del día cual sabemos/ están abiertas ni en su puerta llabe,/pero jamás se ha bisto ni tenemos/raçón que perro entre ni se trabe,/ni se estorbe perrero asalariado,/que el tenplo que es de dios se está guardado" f. 67v.

85 "La terçera raçón, que suciamente/al tenplo, do han de entrar justificados//entran los cuerpos suçios claramente,/los bestidos en todo mal guardados,/los zapatos que pisan la corriente/llenos de suçiedad y traspasados,/con ellos entran y en el tenplo pisan,/suenan y escupen y a la amiga abisan." F. 66r.

"Otra cosa también en sus tenplos tienen,/que los perros se meten cual si fuera/mesón, y a los altares mismos bienen,/ensuçiando y meando donde quiera,/y assí para estas causas se previenen/de hombres que les están echando fuera,/éstos llaman perreros con su renta,/que sólo de echar perros tienen cuenta." F. 67r.

86 "Otrossí que durante el sacrificio/la misa u otra fiesta cual se sea/no les perturbara a su Malefiçio,/que uno conpra, otro bende, otro pasea,/otro se arrisca, y de amoroso biçio/ no mira a Dios, mira lo que desea,/siendo el tenplo tan sólo dedicado/ para adorar a dios glorificado" (f. 66v).

87 "Cuánto mejor estaba el matrimonio/en serbiçio de Dios y su mandado,/mostrando manifiesto testimonio/de ligítimos hijos en su estado,/y no çegados por el bil demonio,/que no ay dellos quien no ande amançebado,/que es más líçito andar adulterando/que casarse, y aun usan el nefando" (f. 62v). 
being ignorant of their own religion, but of actually revelling in this ignorance. To this end he invokes the well-known and widespread metaphor known in French as la foi du charbonnier, or "coalman's faith," the simple everyman who has not a clue about dogmas but possesses a staunch faith and an unshakeable loyalty to the Church, despite his ignorance of its tenets. ${ }^{88}$ It is a sort of glorification of the faith of the ignorant and simple. In Catholic Counterreformation Europe, while deeper knowledge of Church teachings was in theory required (as shown by the trials of the Inquisition), it was also felt to be dangerous, because it threatened not only the acceptance of clerical authority but also the loyalty and obedience that were integral to simple belief. There has been a lot of scholarly discussion on this foi du charbonnier, and we will not weigh in on it here (Cavaillé 2014-15AD, 68; Wirth 2003; Mothu 2010). Rather, what we consider most significant and want to point to is the level of sophisticated knowledge that Taybili shows about contemporary Catholicism.

To recapitulate, Alguazir's treatise describes a distinction between Christians and Muslims that seems to grow clearer and clearer as the text progresses, a distinction in which Muslims stand on one side and Christians on the other, effectively describing the Muslims by negation. Everything he says about Christians finds its corresponding negation among the Muslims. It was somehow an anti-description, a reverse kind of exposition. In his adaptation, Taybili broadens Alguazir's text and changes it by increasing the concrete and detailed description of what Christians do, how they behave, who they truly are. The repudiation is absolute, as the description aims at vilifying, ridiculing, drawing a line between them and us, and probably between the old and the new part of "us," the old Spanish Christian and the new Muslim now safe in the lands of Islam.

\section{Evaluation and Conclusions}

To sum up, the polemical text written by Muhamad Alguazir at the Sa'did court of Sultan Mawlāy Zaydān reflects various aspects of Muslim-Christian relations. The author was an exiled Iberian Muslim, a Morisco from Pastrana, an important centre of Morisco intellectual life in sixteenth-century Castile. Alguazir, perhaps the same person as Diego Alguaçil, entered the circle of Moriscos at the court of Sultan Zaydān in the years after 1608, when Zaydān took power in Marrakesh. Born in Spain, these Moriscos were often used as mediators between the sultan and representatives of Christian powers. In 1610, the need arose to provide the Dutch authorities with a religious text after religious topics were discussed at The Hague during a banquet that marked the signing of a treaty between the Dutch Republic and Sultan Zaydān in 1610. While Alguazir's text is heavily influenced by Ash $^{c}$ arite theological doctrine as formulated by al-Sanūsī, which was dominant in the intellectual religious life at the $\mathrm{Sa}^{\mathrm{c}} \mathrm{did}$ court, it also draws on the author's youth immersed in Castilian Christian culture. As we have seen, he was thoroughly familiar with Luis de Granada's work, of which he makes tacit use not in order to polemize, but rather to illustrate aspects of Islamic theology. Being perhaps familiar with contemporaneous works on non-Christian religions, the author applies the existing European-based quadripartite typological distinctions between Christianity, Judaism, Islam, and paganism. Using al-Sanūsī's creeds, Alguazir aims to show how logically inconsis-

88 "En la fe que el cristiano idiota se ase,/es la fe que çelebran de aquel cuento/del carbonero, que muriendo estaba/y la fe que sabía confesaba./ (f. 68r) Preguntó el confesor en qué creía;/Respondió: 'Padre mío, sólo creo/en lo que manda y al cristiano guía/la santa madre /yglesia y jubileo.' ‘ ¿En qué cree la yglesia?’, repetía/el frayle, 'decí, hermano, en buen deseo", “"en lo que creo yo', y assí se andaba,/y de la yglesia a él no le sacaba" (f. 68v). 
tent Christian (and Jewish) thought is, perhaps even more so than paganism. Thanks to its diplomatic Latin afterlife, we argue, the text became known in Europe, where such Islamic texts remained rare. This polemical tract was then eagerly studied by Dutch, English and German orientalists, and later by Lutheran theologians as well. However, the text also knew a different trajectory, circulating among Moriscos in exile, upon whom it exercised a profound influence. This other trajectory was made possible in part by the Morisco Juan Pérez/Ibrahim Taybili, the most prolific Spanish-writing Morisco, who rendered it in verse. A profound lover of Castilian arts and culture, Taybili deepened the rift between Christians and Muslims by accentuating Christians' logical inconsistencies and moral depravity, while exalting Muslim superiority. This may perhaps be seen as the reaction of someone who was deeply disappointed and bitter that the culture he admired, and to which he believed to have belonged, had rejected him. While Alguazir still had ties with Christians (such as the sultan's Dutch allies and Christians he met at the Moroccan court), albeit indirectly, Taybili no longer had such connections; rather, he became a leading figure of Morisco intellectual life in Tunis and Testour, which tended toward a rejection of all things Catholic that led Taybili and his peers to intensify their polemical tone and cement the divide between the two faiths.

To conclude, the texts we have examined here are in fact three different versions of Alguazir's polemical treatise, where different approaches to comparison, invective, and repudiation speak to shifting contexts of use. Comparisons (as well as analogies and connections) emerge as an important point in all the different iterations of the text, but the thread that connects the different parts of our essay is the contextual transformation of Alguazir's text. Each version of the text-Alguazir's "original," Ahmad b. 'Abd Allāh's Latin Epistola (perhaps based on a now-lost Spanish adaptation by Alguazir), Taybili's versified version, and the Grapius edition of the Latin translation-was created against a different backdrop, and in each one comparisons are employed differently. This is a consequence, as we have shown, of both the individuals involved in the adaptation and, no less importantly, of the readership and wider audience. In Alguazir, the thrust is polemics based on logic and reason (hence its repudiation without invective); in the Latin translation there is a sort of strategic pragmatism (and therefore the tone is less polemical, stressing certain Muslim-Protestant commonalities); in the edition of the Latin translation by Grapius we find Lutheran Orientalist interest in addition, and in Taybili there is a more personal expression and a sense of disillusionment, perhaps even negation of the author's former self. Its aim is also to reinforce Muslim feelings and beliefs among his audience of Moriscos in exile, and therefore there is more invective. The various versions reveal different strategies in contesting Christian beliefs and practices, giving rise to divergent overall discourses. It is only in appearance, or partially, that they are the same text.

\section{Acknowledgements}

The authors of the present essay are preparing a critical edition of the polemical text discussed here. The research leading to this article has been funded by the project "Orientalismo y verdad: la influencia de la erudición oriental en el desarrollo del pensamiento crítico en la España Moderna" (FFI2017-86538-P) (PIs: Fernando Rodríguez Mediano and Mercedes GarcíaArenal) and from the European Union Horizon 2020 research and innovation programme under grant agreement No. 810141 (The European Qur'an).

This paper was originally presented at the international conference: Behaving Like Heathens? Polemical Comparisons and Discourses of Religious Diversity across the Cultures. Biele- 
feld University, 29 November - 1 December 2018, organized by Christina Brauner and Sita Steckel. Another version was presented at the conference Perception of the Other and of Islam through Manuscripts of the Qur'an and Islamic literatures, Università di Napoli l'Orientale, 11 February 2020.

We thank Kasia Starczewska and Teresa Madrid Álvarez Piñer at the CSIC (Madrid), Luis Bernabé Pons of the University of Alicante, and the organizers of said conferences, as well as the participants, for their remarks. We also thank the anonymous reviewers for their helpful comments.

\section{Manuscripts}

- Biblioteca Nacional de España [BNE] Ms. 9074

- Wadham College, Oxford, Ms. A18-1

- Bodleian Library, Oxford, Ms. Arch. Selden B 8

\section{References}

Alegre Carvajal, Esther. 2020. "Identidades de desarraigo y diaspora. La travesia de los moriscos granadinos hasta Pastrana." Anales de Historia del Arte 30 (November): 209-36. https://doi.org/10.5209/anha.72180.

Aquinas, Thomas. 1895. "Secunda Secundae Summa Theologiae." In Opera Omnia T. VIII. Rome: Typographia Polyglotta S. C. de Propaganda Fide.

Balabarca-Fataccioli, Lisette. 2020. "Polémica anticristiana en el Norte de África. El caso de los moriscos españoles." Transmodernity. Journal of Peripheral Cultural Production in the Luso Hispanic World 9 (4): 83-102.

Ben-Abdala, Ahmet. 1705. Mohammedani Epistola Theologica de Articulis Quibusdam Fidei. Edited by Zacharias Grapius. Rostock: N. Schwiegerovit.

Bernabé Pons, Luis F. 1988. El cántico islámico del morisco hispanotunecino Taybili. Zaragoza: Institución Fernando el Católico.

- 1998. "El texto morisco del evangelio de San Bernabé." In El texto morisco del evangelio de San Bernabé. Granada: Universidad de Granada. http://www.cervantesvirtual.com /bib/portal/lmm/autor_evangelio.shtml.

. 2017. "Ibrāhīm Ṭaybilī." In Christian-Muslim Relations. A Bibliographical History., edited by David Thomas and John Chesworth. Vol. 31. Western and Southern Europe (1600-1700) 9. Leiden: Brill.

Cardaillac, Louis. 1977. Morisques et chrétiens: un affrontement polémique, 1492-1640. Paris: Klincksieck.

Cavaillé, Jean. 2014-15AD. "La Question de l'irréligion populaire, à la rencontre de l'histoire et de l'anthropologie." Institut d'Histoire de la Réformation, Bulletin Annuel 36: 55-69.

Champion, Justin. 2010. “ 'I Remember a Mahometan Story of Ahmed Ben Edris': Freethinking Uses of Islam from Stubbe to Toland." Al-Qanțara 31 (2): 443-80. https://doi.org/https: //doi.org/10.3989/alqantara.2010.v31.i2.239.

Colominas Aparicio, Mònica. 2018. The Religious Polemics of the Muslims of Late Medieval Christian Iberia. Identity and Religuous Authority in Mudejar Islam. Leiden: Brill. 
2020. "Comparing Comparisons in Muslim Polemical Writings from Christian Iberia and Exile: Muḥammad Al-Qaysī's Kitāb Miftāh Al-Dīn and the Anonymous Tratado de Los Dos Caminos." Entangled Religions 11 (4). https://doi.org/10.46586/er.11.2020.86 93.

Craster, Henry H. E., Noël Denholm-Young, and Falconer Madan, eds. 1980. A Summary Catalogue of the Western Manuscripts in the Bodleian Library at Oxford. Vol. 2. Munich: Kraus.

El-Rouayheb, Khaled. 2015. Islamic Intellectual History in the Seventeenth Century. Scholarly Currents in the Ottoman Empire and the Maghrib. Cambridge: Cambridge University Press.

Galmés de Fuentes, Álvaro, and Juan Carlos Villaverde Amieva, eds. 2005. Tratado de los dos caminos, por un morisco refugiado en Túnez (Ms. S2 de la Colección Gayangos, Biblioteca de la Real Academia de la Historia). Vol. 14. Colección de literatura española aljamiado-morisca. Madrid; Oviedo: Instituto Universitario Seminario Menéndez Pidal; Universidad Complutense de Madrid; Seminario de Estudios Arabo-Románicos.

García-Arenal, Mercedes, and Fernando Rodríguez Mediano. 2010. "Los libros de los moriscos y los eruditos orientales." Al-Qantara 31: 611-46.

- 2013. The Orient in Spain: Converted Muslims, the Forged Lead Books of Granada and the Rise of Orientalism. Vol. 142. Numen Book Series. Leiden: Brill.

García-Arenal, Mercedes, and Gerard Wiegers. 2013. L'uomo Dei Tre Mondi: Storia Di Samuel Pallache, Ebreo Marocchino Nell'Europa Del Seicento. Rome: Viella. . 2014a. Samuel Pallache: Koopman, Kaper En Diplomaat Tussen Marrakesh En Amsterdam. Amsterdam: Amsterdam University Press.

, eds. 2014b. The Expulsion of the Moriscos from Spain: A Mediterranean Diaspora. Leiden: Brill.

. 2019. "Introduction to Polemical Encounters." In Polemical Encounters: Christians, Jews, and Muslims in Iberia and Beyond, 1-21. University Park: Pennsylvania State University Press.

Harvey, Leonard P. 1989. "A Second Morisco Manuscript at Wadham College, Oxford: A 18.15." Al-Qatara 10 (1): 257-72.

Heering, Jan Paul. 2019. "De paus van Holland' en zijn contacten met Oldenbarneveld, Maurits en Grotius, Johannes Wtenbogaert en de politiek.” In Tolerantie in Turbulente tijden. Johannes Wtenbogaert (1557-1644) en denkers van nu over verdraagzaamheid, edited by Eric Cossee, Joost Röselaers, and Marthe de Vries, 71-76. Utrecht: Kok.

Hajjī, Muhammad. 1976. L'activité intellectuelle au Maroc à l'époque sa'dide. Vol. 2. Rabat: Dar El Maghrib.

Klein, Dietrich. 2008. "Muslimischer Antitrinitarismus Im Lutherischen Rostock. Zacharias Grapius Der Jüngere Und Die Epistola Theologica Des Ahmad Ibn Abdallâh." In Wahrnehmung Des Islam Zwischen Reformation Und Aufklärung, edited by Birte Platow and Dietrich Klein, 41-60. Munich: Wilhelm Fink.

Krech, Volkhard. 2017. "Typology." 1. KHK Working Paper Series. Bochum: Käte Hamburger Kolleg.

Loop, Jan. 2013. Johann Heinrich Hottinger. Arabic and Islamic Studies in the Seventeenth Century. Oxford: Oxford University Press.

Mothu, Alain. 2010. "De la foi du charbonier à celle du héros (et retour)." Les dossiers du Grihl, Libertinage, athéisme, irreligion,. https://journals.openedition.org/dossiersgrihl/3393.

Mout, Nicolette. 1978. "Calvinoturcisme in de zeventiende eeuw: Comenius, Leidse oriëntalisten en de Turkse bijbel." Tijdschrift voor geschiedenis 91: 576-607. 
Mulsow, Martin. 2010. "Socinianism, Islam and the Radical Uses of Arabic Scholarship." AlQanțara 31 (2): 448-80. https://doi.org/https://doi.org/10.3989/alqantara.2010.v31 .i2.242.

Oliver Asín, Jaime. 1933. "Un morisco de Túnez, admirador de Lope.” Al-Andalus 1 (2): 40950.

Olson, Caitlyn. 2020. "Beyond the Avicennian Turn: The Creeds of Muhammad B. Yūsuf AlSanūsī (D. 895/1490)." Studia Islamica 115: 101-40.

Saldanha, António de. 1997. Crónica de Almançor, sultão de Marrocos (1578-1603). Edited by António Dias Farinha. Lisbon: Instituto de Investigação Científica Tropical.

Smith, Jonathan Z. 1998. "Religion, Religions, Religious." In Critical Terms for Religious Studies, edited by Mark C. Taylor, 269-84. Chicago: Chicago University Press.

Soto, Teresa. 2019. "Poetics and Polemics: Ibrahim Taybili's Anti-Christian Polemical Treatise in Verse." In Polemical Encounters: Christians, Jews, and Muslims in Iberia and Beyond, edited by Mercedes García-Arenal and Gerard Wiegers, 332-56. University Park: Pennsylvania State University Press.

Steckel, Sita. 2018. "Verging on the Polemical: Towards an Interdisciplinary Approach to Medieval Religious Polemic." Medieval Worlds 7: 2-60.

van Koningsveld, Pieter Sjoerd, Qasim al-Samarra'i, and Gerard Wiegers, eds. 2015. Ahmad Ibn Qâsim al-Hajarî. Kitāb Nāṣir al-Dīn Alā 'l-Qawm al-Kāfirīn = (The Supporter of Religion against the Infidels). General Introduction, Critical Edition and Annotated Translation. Reedited, Revised, and Updated in the Light of Recent Publications and the Primitive Version Found in the Hitherto Unknown Manuscript Preserved in Al-Azhar. Fuentes Arábico-Hispanas 35. Madrid: CSIC.

van Koningsveld, Pieter Sjoerd, and Gerard Wiegers. 2019. "Marcos Dobelio's Polemics Against the Authenticity of the Granadan Lead Books in Light of the Original Arabic Sources." In Polemical Encounters: Christians, Jews, and Muslims in Iberia and Beyond, edited by Mercedes García-Arenal and Gerard Wiegers, 203-68. University Park: Pennsylvania State University Press.

Wiegers, Gerard. 1988. A Learned Muslim Acquaintance of Erpenius and Golius: Aḥmad B. Kâssim Al-Andalusî and Arabic Studies in the Netherlands. Leiden: Rijksuniversiteit. 1994. Islamic Literature in Spanish and Aljamiado. Yça of Segovia (Fl 1450) His Antecedents and Successors. Leiden: Brill.

- 1995. "Muhammad as the Messiah: A Comparison of the Polemical Works of Juan Alonso with the Gospel of Barnabas." Bibliotheca Orientalis 52 (3/4): 245-91.

. 1996. "The Andalusi Heritage in the Maghrib: The Polemical Work of Muhammad Alguazir (Fl. 1610)." In Poetry, Politics and Polemics. Cultural Transfer Between the Iberian Peninsula and North Africa, edited by Geertz Jan van Gelder, Edward de Moor, and Otto Zwartjes, 107-32. Amsterdam: Rodopi.

—. 2001. "Review of Bernardo Pérez de Chinchón Antialcorano. Diálogos christianos (conversión y evangelización de moriscos)." Aljamía. Anuario de información bibliográfica 14: 451-55.

. 2010. "Learned Moriscos and Arabic Studies in Europe." Al-Qanțara 31 (2): 587-610. . 2014. "The Expulsion of 1609-1614 and the Polemical Writings of the Moriscos Living in the Diaspora." In The Expulsion of the Moriscos from Spain: A Mediterranean Diaspora, edited by Mercedes García-Arenal and Gerard Wiegers, 389-412. Leiden: Brill. 
2017a. "Moriscos in North Africa After the Expulsion from Spain in 1609 and Their Discourse About Exile and Diaspora." In Early Modern Ethnic and Religious Communities in Exile, edited by Yosef Kaplan, 165-78. Cambridge: Cambridge Scholars Publishing.

_ 2017b. "Muhamad Alguazir." In Western and Southern Europe (1600-1700), edited by David Thomas and John A. Chesworth, 9:133-42. Christian-Muslim Relations. A Bibliographical History. Leiden: Brill.

Wirth, Jean. 2003. "La naissance du concept de croyance (XII-XVII siècles)." In Sainte Anne est une sorcière et autres essais, edited by Jean Wirth, 113-76. Geneva: Droz. 